DOI 10.14746/ssp.2020.2.1

Mirosław BANASIK

Uniwersytet Jana Kochanowskiego w Kielcach

ORCID: 0000-0002-9358-1240

\title{
Bezpieczeństwo Europy Środkowo-Wschodniej w aspekcie zagrożeń płynących z Federacji Rosyjskiej
}

Streszczenie: Imperialna polityka Federacji Rosyjskiej zmierza do zmiany porządku międzynarodowego ustanowionego po zakończeniu zimnej wojny i odbudowania strefy wpływów. Celem artykułu jest ocena bezpieczeństwa krajów Europy Środkowo-Wschodniej pod kątem zagrożeń płynących z Rosji. W artykule przedstawiono strategiczne wyzwania stojące przed NATO i wskazano na pożądane kierunki adaptacji NATO do zmieniających się uwarunkowań bezpieczeństwa międzynarodowego.

Słowa kluczowe: Europa Środkowo-Wschodnia, Federacja Rosyjska, NATO, adaptacja, wyzwania, bezpieczeństwo, zagrożenia

\section{Wstęp}

A neksja Krymu przez Federację Rosyjską (FR) w 2014 roku, destaA bilizacja wschodniej Ukrainy i militaryzacja Obwodu Kaliningradzkiego stanowią dla Europy, a szczególnie dla środkowo-wschodniej jej części bezprecedensowe wyzwania w sferze bezpieczeństwa. Niekorzystne zjawiska zachodzą również wewnątrz terytorium państw europejskich i na ich granicach. W ostatnich kilku latach obserwuje się radykalizowanie Europy, ekstremizmy, brutalne ataki na ludzi prowadzone pod hasłami tzw. Państwa Islamskiego, a także narastające problemy związane z nienotowaną do tej pory skalą zjawisk migracyjnych. Oczekuje się, że poziom bezpieczeństwa będzie się stale obniżał ze względu na długotrwały i trudny do przewidzenia charakter zagrożeń oraz ich transnarodowy charakter (Xavier, 2016, s. 7).

Na podstawie badań wstępnych ustalono, że najgroźniejsze dla środkowo-wschodniej części Europy są zagrożenia płynące z imperialnej polityki Rosji, która zmierza do rewizji ładu międzynarodowego ustanowionego po zakończeniu zimnej wojny i odbudowy strefy wpływów. 
Dążąc do eskalacji dominacji w wymiarze strategicznym za pomocą wojny hybrydowej, której nieodłączną częścią jest wojna w cyberprzestrzeni, wywołuje polityczne i militarne dysproporcje wobec Sojuszu Północnoatlantyckiego oraz pojedynczych jej członków. Polityka Władimira Putina zmierza nie tylko do podważania europejskich zasad prawa i utrzymania dominacji w byłych republikach Związku Radzieckiego, ale przede wszystkim do destabilizacji demokracji w Stanach Zjednoczonych i państwach europejskich, poprzez oddziaływanie w sferze informacyjnej. Moskwa prowadzi od 2008 roku zakrojoną na dużą skalę modernizację swoich sił zbrojnych, w tym nuklearnych, pozyskuje zdolności do prowadzenia agresywnych działań, angażuje siły zbrojne poza własnym terytorium i dąży do ustanowienia baz wojskowych zarówno w Europie, jak i poza nią (Lindley-French, 2017, s. 11).

NATO w Europie szuka skutecznych środków potrzebnych do przeciwstawienia się ograniczonej wojnie prowadzonej przez FR. Z drugiej strony zdolności militarne Stanów Zjednoczonych w Europie stale się kurczą. Strategiczna spójność państw członkowskich staje pod znakiem zapytania, szczególnie po objęciu władzy przez Donalda Trampa. Bezpieczeństwo państw członkowskich położonych w sąsiedztwie z Rosją jest na najniższym poziomie od czasów zimnej wojny. Ze względu na różnicę w postrzeganiu zagrożeń oraz dwuznaczności wynikające z prowadzenia wojny hybrydowej wyraźnie narasta napięcie wokół mechanizmów obrony kolektywnej.

Wnioski wyciągnięte z konfliktu na Ukrainie wskazują, że w sytuacji gwałtownego wdarcia się w głąb terytorium sojuszniczego wojsk FR i prowadzenia otwartego konfliktu zbrojnego zagrożonego eskalacją nuklearną, reakcja Sojuszu ze względu na długie procesy decyzyjne i brak szybkich mechanizmów wdrażania procedur zarządzania kryzysowego będzie prawdopodobnie spóźniona. Nie może więc dziwić fakt, że niektóre państwa członkowskie, szczególnie te odczuwające największe zagrożenie ze strony FR, są skłonne do rekonstrukcji własnych mechanizmów obronnych, ponoszenia większych obciążeń finansowych na bezpieczeństwo i pozyskiwania nowych, kosztownych systemów uzbrojenia (na przykład obrony przeciwrakietowej) czy deklarowania gotowości do rozmieszczenia na własnym terytorium taktycznej broni jądrowej (Doran, 2017, s. 8).

Tak zidentyfikowana sytuacja problemowa prowadzi do sformułowania następujących problemów badawczych: 1) Jakie wyzwania strategiczne stoją przed Sojuszem Północnoatlantyckim? 2) Jakie są pożądane 
kierunki adaptacji NATO do zmieniających się uwarunkowań międzynarodowych?

Celem badań, których rezultaty zaprezentowano w niniejszym artykule było dokonanie oceny wyzwań dla państw Europy Środkowo-Wschodniej płynących ze wschodu oraz zidentyfikowanie przedsięwzięć, które powinien podjąć Sojusz Północnoatlantycki, aby zapewnić bezpieczeństwo międzynarodowe w warunkach agresywnych wobec Zachodu zamiarów strategicznych Rosji. W procesie badawczym zastosowano problemowo-diagnostyczne podejście badawcze. Dominującymi metodami była indukcja i dedukcja, analiza i krytyka literatury oraz bierna obserwacja nieuczestnicząca.

\section{Strategiczne i operacyjne wyzwania dla NATO}

Celem strategicznym Rosji jest osłabienie Zachodu i zmiana europejskiego porządku bezpieczeństwa (euroazjatyckiego). Moskwa będzie prawdopodobnie dążyła do ograniczenia obecności Stanów Zjednoczonych w Europie, podważenia wiarygodności NATO i dezintegracji Unii Europejskiej. Rosja postrzega Stany Zjednoczone, NATO i Unię Europejską jako relatywnie słabe podmioty i będzie dążyła do wykorzystania występujących w nich podziałów. Rosja wszelkimi sposobami będzie dążyła do tego, aby USA koncentrowały się na własnych sprawach wewnętrznych i nie były skłonne do politycznego angażowania się w sprawy europejskie oraz redukowały potencjał wojsk stacjonujących w Europie. Polityczny, ekonomiczny i społeczny kryzys europejski i narastające podziały wewnątrz Unii Europejskiej oraz zmniejszający się budżet z powodu Brexitu nie będzie sprzyjał angażowaniu się państw członkowskich w jakikolwiek konflikt międzynarodowy. Rosja w relacjach z Zachodem będzie prawdopodobnie w pierwszej kolejności dążyła do osiągania własnych celów za pomocą instrumentów niemilitarnego oddziaływania i posługiwała się sprawdzonymi metodami, takimi jak korupcja, szpiegostwo, działania wywrotowe czy propaganda i dezinformacja zmierzająca do pogłębienia występujących podziałów politycznych w NATO i UE oraz próbowała wbić klin w relacje euroatlantyckie (Gotkowska, 2017, s. 3).

Ocenia się, że największym wyzwaniem dla NATO jest przeciwstawienie się narastającym zdolnościom do prowadzenia klasycznych i agresywnych działań ekspedycyjnych oraz modernizowanej broni nuklearnej sił zbrojnych Federacji Rosyjskiej. W Zachodnim Okręgu Wojskowym 
dokonywane są zmiany struktur organizacyjnych oddziałów i związków taktycznych wojsk lądowych mające na celu zwiększenie potencjału i mobilności oraz gotowości do wykonywania gwałtownych uderzeń przeciwko siłom zbrojnym państw NATO (Kuczyński, 2015). Szczególny niepokój budzi tworzenie nowych jednostek powietrzno-desantowych oraz modernizacja istniejących, które wyposażane w nowy sprzęt są w stanie prowadzić samodzielne operacje lądowe (Boston, 2018, s. 6). Narastają dysproporcje pomiędzy Rosją a państwami NATO w Europie występujące w obszarze zdolności konwencjonalnych, szczególnie ze względu na gwałtowne redukcje ciężkich, amerykańskich brygad pancernych stacjonujących w Niemczech dokonane w latach 2000-2013 (Vandiver, 2013). Najbardziej widoczne dysproporcje pomiędzy państwami bałtyckimi a Rosją zaobserwowano w Obwodzie Kaliningradzkim po aneksji Krymu w 2014 roku. Na przestrzeni 2016 i 2017 roku zainstalowano tam nowe typy zestawów przeciwlotniczych, przeciwokrętowe zestawy rakietowe Bastion z pociskami Onyx oraz wyrzutnie rakiet balistycznych Iskander, przenoszących głowice nuklearne, które są w stanie razić cele na odległość do $500 \mathrm{~km}$ (Gotkowska, 2017, s. 3), a także wprowadzono na Bałtyk dwie najnowocześniejsze korwety rakietowe typu Bujan-M z bronią atomową na pokładzie (Gac, 2019, s. 80; Dwie..., 2016; NATO, 2016). Dowódca Floty Bałtyckiej w lutym 2018 roku poinformował, że $\mathrm{w}$ ramach modernizacji podległe mu jednostki otrzymają okręty rakietowe, systemy obrony przeciwlotniczej S-400 Triumf ${ }^{1}$, zmodernizowane samoloty wielozadaniowe Su-30SM oraz śmigłowce Ka-27M (Rosja..., 2018). Nowe, kompleksowe systemy uzbrojenia tworzące tzw. zdolności uniemożliwiające dostęp NATO do regionu Morza Bałtyckiego i Centralnej Europy, nazywane są w literaturze anglojęzycznej zdolnościami anti-access lub area denial A2 $\mathrm{AD}^{2}$. Szczególny niepokój budzi seria ro-

1 System S-400 Triumf to obecnie najnowocześniejszy kompleks przeciwlotniczy i przeciwrakietowy znajdujący się w służbie rosyjskich sił zbrojnych. Może jednocześnie namierzać i naprowadzać rakiety na wiele celów. Jego maksymalny zasięg to 400 kilometrów, choć na większych dystansach może zwalczać tylko cięższe i powolniejsze samoloty, np. transportowe czy wczesnego ostrzegania. Według Rosji S-400 jest w stanie skutecznie niszczyć także samoloty skonstruowane w technologii, która zapewnia niską wykrywalność przez radary. Triumf może też zestrzelić pociski manewrujące oraz niektóre typy rakiet balistycznych (Dura, 2017).

2 „Tak zwana koncepcja A2AD to połączenie działań przeciwnika, które ograniczają możliwości militarnego dostępu do danego obszaru, z działaniami utrudniającymi operowanie w obszarze kontrolowanym przez przeciwnika. W tym wypadku chodzi o rozbudowane rosyjskie instalacje, na które składają się przede wszystkim 
syjskich ataków hackerskich na państwa sojusznicze oraz zerwanie przez Moskwę ważnego porozumienia nuklearnego dotyczącego utylizacji nadliczbowego materiału do broni nuklearnej. Jako cenę wznowienia układu, rosyjski prezydent W. Putin przedstawił absolutnie zaporowe warunki i zażądał wycofania wszystkich sił i instalacji NATO za Łabę oraz zniesienie sankcji (Górzyński, 2016).

W odpowiedzi na pogwałcenie przez Rosję prawa międzynarodowego i aneksję Krymu oraz wspieranie separatystów na wschodzie Ukrainy, NATO podjęło szereg działań zapobiegawczych. Odpowiedź Sojuszu była jednak bardzo ostrożna. Na szczycie w Walii podjęto przełomowe decyzje o wzmocnieniu wschodniego obszaru traktatowego $\mathrm{NATO}^{3}$ i priorytetowym traktowaniu gotowości do prowadzenia obrony kolektywnej mimo to, że w tamtym czasie nie osiągnięto konsensusu co do rozmieszczenia wojsk. Jedynie Stany Zjednoczone jednostronnie zobowiązały się do obecności swoich żołnierzy na wschodzie Europy. Zdecydowano również o konieczności podjęcia działań zmierzających do przeciwdziałania zagrożeniom płynącym ze wschodu i zaadaptowania się Sojuszu do zmieniających się uwarunkowań bezpieczeństwa międzynarodowego. Reformy miały być możliwe dzięki zobowiązaniu się państw członkowskich do podniesienia wydatków na obronność do poziomu wynoszącego dwa procent PKB. Zapowiedziano też utworzenie brygady sił bardzo szybkiego reagowania w sile około 5000 żołnierzy w celu podniesienia gotowości NATO do reagowania na nowe zagrożenia, w tym o charakterze hybrydowym (Banasik, 2017, s. 143-161).

Dwa lata później w odpowiedzi na prowokacyjne zachowania Rosji, na szczycie w Warszawie podjęto jeszcze bardziej zdecydowane kroki. Wobec pogarszającej się sytuacji bezpieczeństwa międzynarodowego zdecydowano o konieczności rozmieszczenia i obecności na zasadach rotacyjnych czterech batalionowych grup bojowych w państwach bałtyckich i w Polsce. Decyzja o wzmocnieniu wschodniego obszaru odpowiedzialności traktatowej była wyrazem solidarności Sojuszu i gotowości do prowadzenia obrony kolektywnej w odpowiedzi na jakąkolwiek agre-

systemy radarowe i pociski obrony powietrznej, pociski rakietowe przeznaczone do uderzania w cele lądowe i morskie, a także lotnictwo i marynarka wojenna. Najistotniejsze jest to, że system ten tworzy rodzaj klosza, który utrudnia, czy wręcz uniemożliwia operacje NATO w obszarze zasięgu zdolności A2AD” (Michta, 2016).

3 Działania NATO ograniczały się do prowadzenia misji nadzoru przestrzeni powietrznej Rosji, misji BalticAirPolicing, na Bałtyk skierowano okręty wojenne i rozpoczęto prowadzenie ćwiczeń NATO w państwach Europy Środkowo-Wschodniej. 
sję ze strony Moskwy (Komunikat..., 2016). Od połowy 2017 roku siły wzmocnienia NATO rozlokowane w państwach granicznych liczyły około 4500 żołnierzy ${ }^{4}$. Zgodnie z zapowiedziami docelowo całość jednostek amerykańskich i natowskich obecnych tylko w Polsce będzie liczyła okoto 7 tysięcy żołnierzy ${ }^{5}$. Międzynarodowe siły wzmocnienia są deklarowane na zasadzie dobrowolności, ale ich ciągła rotacja generuje niezwykle wysokie koszty. Obciążenia finansowe stanowią poważne ograniczenie dla rozlokowania na wschodzie większych sił, nawet dla takich państw jak Stany Zjednoczone czy Kanada. Po drugie, liderzy NATO nie chcą prowokować i eskalować napięcia z Rosją rozmieszczeniem w pobliżu jej granic wojsk stanowiących duże znaczenie militarne.

Ze strategicznego punktu widzenia potencjał sił NATO jest raczej symboliczny i wyraża solidarność państw członkowskich do wspólnego ponoszenia odpowiedzialności za bezpieczeństwo, ale jest zbyt mały, aby odstraszyć Rosję. Biorąc pod uwagę oceny Davida Shlapaka rosyjskie wojska mogą zając państwa bałtyckie w ciągu 60 godzin $^{6}$. Można zatem dojść do wniosku, że misją sił wzmocnienia NATO nie jest odparcie rosyjskiego uderzenia, ale ma wymiar polityczny (Khramchikhin, 2018, s. 6). W przypadku rosyjskiej agresji Sojusz musiałby uruchomić artykuł 5 Traktatu Waszyngtońskiego obligujący wszystkich członków do udzielenia wsparcia militarnego zaatakowanemu państwu, co byłoby jednoznaczne z prowadzeniem otwartej wojny przeciwko Rosji (Mitchell, 2015). Aby uniknąć katastrofalnych konsekwencji związanych z konfron-

4 „Batalionowe grupy bojowe to wzmocnione, samodzielne bataliony, które w zależności od państwa liczą od kilkuset do ponad tysiąca żołnierzy. Każdy oddział, który trafi na wschodnią flankę, będzie wielonarodowy, ale będzie miał tzw. państwo ramowe, odpowiedzialne za wystawienie większości sił i dowodzenie całością. W przypadku Polski taką rolę będą pełnić USA, na Litwie - Niemcy, na Łotwie - Kanada, a w Estonii - Wielka Brytania. Do Polski przyjadą także żołnierze z Wielkiej Brytanii, Rumunii i Chorwacji”' (Szef..., 2017).

5 „W styczniu 2017 r. do Polski przyjechało 3,5 tys. żołnierzy amerykańskiej pancernej brygadowej grupy bojowej (ang. ABCT). Jej rozmieszczenie to efekt zobowiązania, jakie władze USA podjęły samodzielnie, obok wspólnej decyzji NATO o rozmieszczenie batalionów. Brygada ma przebywać w Europie w sposób ciągły i rotacyjny, zmieniając się co dziewięć miesięcy. Od lutego oddziały amerykańskiej brygady zaczęły się dyslokować w regionie, by ćwiczyć z innymi europejskimi sojusznikami”" (Macierewicz..., 2017).

${ }^{6}$ Rosyjskie siły zbrojne w Zachodnim Okręgu Wojskowym liczą 27 batalionów manewrowych, 10 dywizjonów artylerii, 4 dywizjony rakietowe, sześć eskadr śmigłowców uderzeniowych, a także pododdziały piechoty morskiej wraz ze środkami wsparcia (Shlapak, 2016, s. 4). 
tacją, NATO powinno podjąć kroki zapobiegawcze na wschodzie własnego terytorium i dać wyraźny przekaz Rosji, że zwycięstwo nie będzie łatwe. W opinii ekspertów osiągając cel skutecznego odstraszania Sojusz powinien posiadać w państwach bałtyckich co najmniej siedem ciężkich brygad, w tym trzech pancernych wraz ze środkami wzmocnienia (Shlapak, 2016, s. 8). Z drugiej jednak strony nawet ograniczona, prowokacyjna postawa wojsk rosyjskich w regionie Europy Wschodniej, może być nie tylko testem zachowania się Sojuszu, ale stać się bezpośrednią przyczyną eskalacji napięcia, które szybko może przerodzić się w otwarty konflikt zbrojny prowadzony na dużą skalę. Tak więc wysunięta obecność wojsk nawet posiadających ograniczone zdolności do prowadzenia bezpośredniej konfrontacji, może w sytuacjach konfliktowych być uzasadnioną przesłanką i wyraźnym sygnałem w kierunku Rosji do poszukiwania niemilitarnych rozwiązań. Rosja w swoich kalkulacjach powinna również uwzględniać możliwość odpowiedzi bronią nuklearną, w przypadku agresji na żołnierzy amerykańskich czy brytyjskich znajdujących się w strefie bezpośrednich działań bojowych (Dempsey, 2017, s. 5).

Problem odstraszania strategicznego NATO jest gorąco dyskutowany od zakończenia szczytu w Warszawie. Poszukuje się rozwiązań zapewniających wiarygodność Sojuszu i właściwe proporcje pomiędzy odstraszaniem konwencjonalnym a nuklearnym. Nie mniej istotne są relacje pomiędzy tymi działaniami. Debata, która toczy się w kręgach politycznych i wojskowych wskazuje na występujące wątpliwości co do ilości oraz wielkości rozmieszczanych oddziałów sił zbrojnych oraz sposobów wykorzystania posiadanych zdolności. Dla przykładu nie ustalono, jaką strategiczną rolę powinny odgrywać samoloty podwójnego przeznaczenia, przygotowane do przenoszenia głowic nuklearnych. W jakich sytuacjach należałoby je wykorzystać do przełamywania rosyjskiej obrony powietrznej i czy będą posiadały odpowiednio wysoki poziom gotowości bojowej do pełnienia takiej roli. Dyskutowane jest wzmocnienie roli komunikacji strategicznej, jako nieodłącznego elementu odstraszania, szczególnie podczas prowadzenia ćwiczeń z użyciem broni nuklearnej (Lindley-French, 2017, s. 16).

Niektórzy krytycy twierdzą, że jakość sojuszniczych sił zbrojnych jest niska, a ich ilość daleko niewystarczająca do tego, aby NATO mogło podjąć bezpośrednią walkę ze zmodernizowanymi wojskami Federacji Rosyjskiej. Nawet jeśli Sojuszowi udałoby się wdrożyć koncepcję globalnych uderzeń oraz prowadzenia bezkontaktowej walki sieciocentrycznej, to i tak nie będzie w stanie prowadzić wojny przeciwko Rosji. 
Arsenał pocisków rakietowych typu Cruise będących w dyspozycji sił powietrznych i marynarki wojennej Stanów Zjednoczonych jest niewystarczający do tego, aby poprzez zaskoczenie i symultaniczne uderzenie zniszczyć strategiczne siły zbrojne Federacji Rosyjskiej. W opinii Aleksandra Khramchikhina nawet połowiczny sukces osiągnięty dzięki jednoczesnemu uderzeniu konwencjonalnemu i nuklearnemu, nie doprowadzi do osiągnięcia przez NATO przewagi strategicznej (Khramchikhin, s. 6). Ocenia się również, że w odpowiedzi na pogarszające się relacje Rosji z Zachodem, państwa sojusznicze nie wdrożyły własnych programów adaptacyjnych. W związku z tym nie można poważnie traktować posunięć NATO. Niektórzy przypuszczają, że programy wzmocnienia bezpieczeństwa Europy Środkowo-Wschodniej polegają na manipulowaniu rozmieszczeniem wojsk i posiadają jedynie wartość retoryczną. Dość kontrowersyjne wydają się też stwierdzenia, że zachodnie elity są skłonne ukarać Rosję za złamanie monopolu Zachodu na nieprzestrzeganie międzynarodowego prawa (Khramchikhin, s. 6).

Jednym z poważniejszych wyzwań dla Sojuszu, poza osiągnięciem zdolności do działania sił wysokiej gotowości bojowej (VJTF) i zmianami w koncepcji sił odpowiedzi NATO jest dostępność sił głównych i możliwość ich skierowania w razie konieczności na teatr działań operacyjnych. Szacuje się, że mobilizacja zasadniczych sił zbrojnych NATO potrwa od trzech do sześciu miesięcy. Dużym problemem pozostaje przemieszczenie zmobilizowanych wojsk przez państwa Europy Środkowo-Wschodniej w rejon przyszłych działań operacyjnych. Obecnie występuje niestety wiele ograniczeń natury prawnej i proceduralnej. Przeszkodą w zapewnieniu właściwej mobilności jest niedostosowanie infrastruktury drogowej i kolejowej państw sojuszniczych. Nieprzygotowane do przyjęcia wojsk z ciężkim sprzętem są też porty lotnicze i morskie (Pre-Ministerial..., 2016).

Dużą uwagę w NATO poświęca się problematyce utrzymania wysokiej gotowości bojowej sił zbrojnych, ich przygotowania do operowania w warunkach nowych zagrożeń hybrydowych i pozyskania krytycznych zdolności operacyjnych. Sojusz wciąż boryka się z problemem braków występujących głównie w obszarze broni precyzyjnego rażenia, strategicznego transportu powietrznego, pozyskiwania informacji wywiadowczych, rozpoznania i nadzoru powietrznego, obrony przeciwrakietowej. Pojawiają się coraz częściej głosy o potrzebie wymiany systemów AWACS oraz dokonania zmian $\mathrm{w}$ programie smart defence (Lindley-French, 2017, s. 14). 
Nie mniej ważne są wyzwania związane z logistycznym zabezpieczeniem prowadzonych przez NATO operacji. Celowym jest posiadanie cywilno-wojskowych zdolności, które odpowiadałyby potrzebom występującym zarówno w czasie pokoju, jak i kryzysu oraz wojny. Konieczna jest modernizacja infrastruktury logistycznej zapewniającej sprawne przemieszczanie wojsk i zaopatrzenia. Problemy logistyczne szczególnie ostro uwidoczniły się w czasie wzmacniania wschodniej flanki NATO oraz w trakcie przemieszczania ze Stanów Zjednoczonych do Polski pancernej brygadowej grupy bojowej.

Kształtowanie odporności w kontekście zagrożeń hybrydowych stało się wiodącym tematem szczytu NATO w Warszawie, a zdolności do stawiania oporu są w coraz większym stopniu postrzegane jako element wszechstronnej strategii bezpieczeństwa Sojuszu, stanowiący uzupełnienie środków odstraszania i wzmacniania bezpieczeństwa opartego na instrumencie militarnym. Wojna hybrydowa wyrażająca się agresją poniżej progu przywołania artykułu 5 Traktatu Waszyngtońskiego wymusza na Sojuszu posiadanie odporności gwarantującej zdolność do szybkiego przemieszczania niezbędnych jednostek wojsk i sprzętu w dowolny rejon obszaru traktatowego, w przypadku zbliżającego się zagrożenia lub bezpośredniego ataku oraz zapewnienia pełnego i niezakłóconego dostępu do infrastruktury sojuszniczej. Po drugie Sojusz musi być w stanie przewidywać, rozpoznawać i odpierać uderzenia hybrydowe oraz minimalizować ich niszczący wpływ na sferę społeczną, polityczną i wojskową (Odporność..., 2016). W aspekcie wojny hybrydowej ukierunkowanej na społeczeństwo, kluczową rolą staje się ochrona ludności, bo bez niej nie będzie możliwa projekcja sił zbrojnych Sojuszu. Wyzwaniem jest również ustalenie gdzie, kiedy i jak NATO powinno się angażować w pomoc sprawowania władzy i udzielania wsparcia w sytuacjach nadzwyczajnych, które mogą wystąpić w państwach członkowskich, a także dla zapewniania wymaganego poziomu ochrony infrastruktury czy na rzecz efektywnego zarządzania sytuacjami związanymi z wystąpieniem kryzysu migracyjnego. NATO powinno również rozważyć możliwość angażowania się na rzecz zapewniania bezpieczeństwa wewnętrznego państw członkowskich w sytuacjach pojawienia się znacznych zagrożeń terrorystycznych lub międzynarodowej przestępczości zorganizowanej (Lindley-French, 2017, s. 15).

Szczyt NATO w Warszawie w 2016 roku zaowocował zacieśnieniem relacji z Unią Europejską (EU) i skonkretyzował obszary współpracy, w tym dotyczące przeciwdziałania zagrożeniom hybrydowym, zwiększa- 
nia odporności na zagrożenia, budowania zdolności obronnych, cyberobrony i bezpieczeństwa morskiego (Komunikat..., 2016). Aż 24 punkty spośród 42 przyjętego planu współpracy poświęcono problematyce wojny hybrydowej. Duże nadzieje pokłada się w powstającym w Finlandii wspólnym NATO-EU centrum zajmującym się problematyką prowadzonej przez Rosję wojny hybrydowej (Waterman, 2016). Wyzwaniem dla obydwu organizacji, wymagającym podejmowania działań adaptacyjnych jest Brexit. Wielka Brytania odgrywała dużą rolę w dostarczaniu dla sojuszników europejskich informacji wywiadowczych oraz była liderem w sferze bezpieczeństwa i obronności europejskiej. Dla bezpieczeństwa europejskiego partnerstwo strategiczne NATO z EU nigdy nie było tak ważne jak obecnie. Bliska współpraca tych dwóch organizacji międzynarodowych jest ważnym elementem rozwiązywania sytuacji kryzysowych i prowadzenia operacji na zasadzie comprehensive approach, które wymaga efektywnego zastosowania zarówno środków militarnych, jak i cywilnych (Relations..., 2016). Skuteczna EU jest w interesie Sojuszu, gdyż ma i będzie miała w przyszłości poważny wpływ na realizację zasadniczych misji NATO (Lindley-French, 2017, s. 12).

Z przeprowadzonych badań wynika, że największym wyzwaniem dla NATO jest przygotowanie się do wojny, która może mieć miejsce w przyszłości, a w opracowaniach anglojęzycznych jest nazywana hiperwojną. Ocenia się, że będzie ona konsekwencją połączenia nowych technologii i wykorzystania zachodzących pomiędzy nimi wzajemnych oddziaływań. Rewolucja technologiczna znacznie przyspieszy tempo prowadzenia konfliktu i pozwoli na skrócenie procesu decyzyjnego. Oczekuje się, że w przyszłej wojnie występować będzie zjawisko znacznej kompresji czasu i osiąganych efektów, jednak procesy dowodzenia niekoniecznie będą przebiegały w sposób bardziej zautomatyzowany. Dążyć się będzie do wytworzenia ogólnego chaosu, który z założenia ma doprowadzić do kapitulacji atakowanej strony. Ocenia się, że coraz większe zaufanie zachodnich cywilizacji do Internetu doprowadzi do uzależnienia ludzi od mediów społecznościowych, co ułatwi manipulowanie nimi i podobnie jak w wojnie hybrydowej doprowadzi do podziałów pomiędzy sferą militarną a cywilną. Oddziaływanie w cyberprzestrzeni na cywilną infrastrukturę spowoduje dezorganizację wszelkich usług świadczonych dla ludności, co znacznie utrudni życie i podniesie stopień niepewności. Ocenia się, że najgroźniejszy jest scenariusz połączenia wojny hybrydowej z wojną w cyberprzestrzeni i hiperwojną, który tworzy nową ideę wojny prowadzonej pomiędzy rozwiniętymi społeczeństwami (Allen, 2017, s. 7). 


\section{Kierunki adaptacji NATO do zmieniających się uwarunkowań międzynarodowych}

Prezydent Donald Tramp już w czasie kampanii prezydenckiej krytycznie wypowiadał się pod adresem NATO, szczególnie w aspekcie zastosowania artykułu 5 Traktatu Waszyngtońskiego i wydatków sojuszników ponoszonych na obronność. Dał wyraźny sygnał, że bezpieczeństwo globalne nie może opierać się na Stanach Zjednoczonych (,,Bild”..., 2017), a państwa członkowskie muszą więcej zrobić dla poprawy zdolności do prowadzenia obrony kolektywnej. W rzeczywistości NATO robi zbyt mało na rzecz zagrożeń obecnych w przestrzeni publicznej, a dotyczących niekontrolowanej migracji i coraz częściej występujących w Europie zjawisk terrorystycznych. Sojusznicy tłumaczą się brakiem wystarczających środków i obawami związanymi z prowokowaniem Rosji lub antagonizowaniem społeczeństwa muzułmańskiego.

Ocenia się, że adaptacja Sojuszu do nowych uwarunkowań międzynarodowych powinna $\mathrm{w}$ pierwszej kolejności zmierzać do obniżania napięcia w relacjach z Rosją i zredukowania ryzyka konfliktu, a także zidentyfikowania obszarów wzajemnej współpracy. Prowadzenie polityki zapewniającej Rosję o niezwiększaniu przez NATO ilości wojsk na wschodzie (Dempsey, 2017, s. 8) nie jest rozwiązaniem długofalowym. Potrzebna jest nowa polityczna strategia NATO wobec Rosji, obejmująca całokształt problematyki bezpieczeństwa euroatlantyckiego, której celem powinno być w pierwszej kolejności doprowadzenie do zaprzestania agresji na Ukrainie i utrzymanie pokoju w Europie (Vershbow, 2017, s. 6). W sytuacji aneksji Krym, wspierania separatystów ze wschodniej Ukrainy i złamania przez Rosję podstawowych norm prawa międzynarodowego oraz politycznego porozumienia w ramach Konferencji Bezpieczeństwa i Współpracy w Europie z 1975 roku, które stworzyło fundament dla dialogu Wschodu z Zachodem jeszcze w czasach zimnej wojny, anachroniczne wydają się działania Sojuszu opierające się na zapisach Aktu Stanowiącego o Wzajemnych Stosunkach, Współpracy i Bezpieczeństwie NATO z Rosją z 1997 roku (Henzel, 2014). NATO musi utrzymywać z Rosją dialog i podejmować niezbędne działania dyplomatyczne. Należy jednocześnie dążyć do obniżania ryzyka eksplozji przypadkowego konfliktu, przywrócenia stabilności we wzajemnych relacjach oraz zwiększyć przewidywalność aktywności militarnych.

Szczyt NATO w Brukseli w 2018 roku był dobrą okazją do zdefiniowania długotrwałych celów adaptacji Sojuszu do nowych wyzwań, któ- 
re powinny stanowić podstawę do opracowania i opublikowania nowej koncepcji strategicznej NATO. Adaptacja jednak nie jest wydarzeniem, a raczej długotrwałym procesem przygotowującym NATO do redukowania ryzyka, podejmowania wyzwań i przeciwstawiania się zagrożeniom w średniej i długiej perspektywie czasowej. W drugiej dekadzie XXI wieku Sojusz powinien być forum politycznej solidarności, zapewniać skuteczne odstraszanie i promować kolektywną obronę. Nadrzędnym celem powinno być budowanie silnych, wiarygodnych i elastycznie funkcjonujących sił zbrojnych, zdolnych do podejmowania natychmiastowej walki w wymiarze lądowym, powietrznym, morskim, kosmicznym i informacyjnym, w tym w cyberprzestrzeni (Lindley-French, 2017B, s. 10).

Doświadczenia ostatniej dekady wskazują na coraz większą dynamikę współczesnego środowiska bezpieczeństwa. Zagrożenia stają się coraz bardziej kompleksowe i mogą się materializować nieoczekiwaną konfrontacją z państwami członkowskimi NATO. W aspekcie posiadania przez Rosję zdolności do kilkudziesięciogodzinnej mobilizacji i rozwinięcia setek tysięcy wojsk (Shlapak, 2016, s. 8), NATO powinno osiągnąć gotowość do natychmiastowego odparcia uderzenia. Koszty porażki w początkowym stadium konfliktu są bowiem potencjalnie o wiele wyższe niż w przeszłości. W opinii Bena Hodgesa kluczowym dla reaktywności NATO jest szybkość rozpoznawania zagrożeń, szybkość podejmowania decyzji politycznych do użycia sił VJTF i szybkość osiągania gotowości wojsk do działań operacyjnego (Hodges, 2015). NATO powinno zmienić kulturę instytucjonalną i procesową na poziomie politycznym tak, aby najważniejsze decyzje dotyczące odpowiedzi na zagrożenia, a szczególnie związane z wykorzystaniem sił zbrojnych były podejmowane w ciągu kilku godzin a nie dni. Koniecznością staje się dokonanie zmian w systemie ostrzegania, aby nie powtórzyła się sytuacja z 2014 roku. I w końcu należy uprościć procedury, aby politycy w sytuacji konieczności sprawnego rozwiązywania sytuacji kryzysowej nie zastanawiali się nad ich zrozumieniem (Brzezinski, 2017, s. 9). Jeśli NATO chce na czas przeciwstawić się agresji, to konieczne jest większe zaufanie do wojskowych. W sytuacji prowadzenia przez Rosję niezapowiedzianych ćwiczeń i demonstrowania gotowości do prowadzenia walki, Sojusz musi być w tym samym czasie gotowy do obrony, dlatego też dowódca strategiczny SACEUR musi posiadać uprawnienia do podnoszenia gotowości bojowej i przyjmowania ugrupowania bojowego, co najmniej przez siły odpowiedzi NATO.

Przegląd struktur dowodzenia NATO dokonany po szczycie w Warszawie wykazał, że Sojusz nie jest w stanie sprostać potrzebie jednoczesnego 
prowadzenia dwóch dużych operacji i jednocześnie sześciu mniejszych. Rekomenduje się taką adaptację struktury, która pozwoliłaby na dowodzenie operacjami o charakterze hybrydowym, w tym w wymiarze cybernetycznym i informacyjnym, a także podejmowanie wyzwań związanych z prowadzeniem hiperwojny na terytorium traktatowym, z jednoczesnym zachowaniem gotowości do podejmowania walki z terroryzmem i prowadzenia operacji reagowania kryzysowego poza terytorium sojuszniczym (Lindley-French, 2017B, s. 15). Dążąc do zwiększonej obecności wojsk sojuszniczych w państwach Europy Środkowo-Wschodniej oraz w obliczu dużej aktywności wojsk rosyjskich w basenie Morza Barentsa i regionu Arktyki ministrowie obrony na spotkaniu w listopadzie 2017 roku podjęli decyzję o konieczności sformowania dowództwa atlantyckiego oraz dowództwa logistycznego (NATO..., 2017).

Zadaniem dowództwa atlantyckiego będzie ochrona linii komunikacyjnych, niezbędnych do przemieszczania sprzętu i zaopatrzenia pomiędzy Stanami Zjednoczonymi a Europą. Wzrastająca aktywność rosyjskiej marynarki wojennej, a szczególnie okrętów podwodnych pomiędzy Grenlandią, Islandią a Wielką Brytanią może wskazywać na próby blokowania dostępu do Europy oraz stanowić zagrożenie dla ruchu transatlantyckiego w potencjalnym konflikcie (Lorenz, 2017). W zakresie odpowiedzialności dowództwa powinny również pozostawać linie komunikacyjne przechodzące przez Morze Północne, Cieśniny Duńskie i Morze Bałtyckie, umożliwiające dostęp do portów morskich w basenie Morza Bałtyckiego. Mają one również szczególnie ważne znaczenie dla obecności wojsk na wschodnich rubieżach obszaru traktatowego. W przypadku konfliktu z Rosją przestrzeń morska stanowić będzie oddzielny teatr prowadzenia działań operacyjnych, dlatego też konieczna jest zmiana obecności strategii morskiej NATO (Rathke, 2017, s. 4).

Dowództwo logistyczne odpowiadałoby za sprawne i szybkie przemieszczenie wojsk, uzbrojenia i sprzętu na obszarze Europy. Obecnie jest ono problematyczne, bowiem po upadku żelaznej kurtyny Sojusz drastycznie zmniejszył wydatki na logistykę. Tymczasem w przypadku konfliktu z Rosją w kierunku wschodniej flanki Sojuszu będą musiały zostać przemieszczone wojska nie tylko z terenu Europy, ale też ze Stanów Zjednoczonych (Stasik, 2017). Aby poprawić możliwości transportowe, szczególnie ciężkiego sprzętu, w Europie konieczne jest adaptacja infrastruktury cywilnej i usunięcie szeregu barier, którymi są niektóre odcinki drogowe i kolejowe, mosty, wiadukty i stacje przeładunkowe. Większość środków transportowych pozostaje w rękach cywilnych, dlatego też nie- 
zbędna jest lepsza współpraca z tymi podmiotami. W opinii Sekretarza Generalnego NATO Jensa Stoltenberga w celu usprawnienia przemieszczania się wojsk konieczna jest koordynacja tego poważnego przedsięwzięcia z Unią Europejską, a współpraca na rzecz poprawy mobilności w Europie powinna być tego wizytówką (Davis, 2017, s. 3). Materializacja tej współpracy już nastąpiła poprzez utworzenie pod koniec 2017 roku w UE dedykowanej do tego celu stałej struktury ${ }^{7}$. Dużym ułatwieniem przekraczania granic państwowych przez przemieszczające się po Europie kolumny wojskowe w czasie pokoju i narastania sytuacji kryzysowej mogłoby być zaproponowane przez gen. B. Hodgesa utworzenie tzw. wojskowej strefy Schengen (Vandiver, 2017).

W SHAPE planuje się utworzenie centrum prowadzenia operacji w cyberprzestrzeni, stanowiącego dodatkowy komponent zmienionej struktury dowodzenia. Tym samym cyberprzestrzeń została uznana jako kolejny obok lądowego, powietrznego i morskiego wymiar prowadzania walki (Cyber..., 2018). Obecnie obrona w cyberprzestrzeni stanowi część kluczowych przedsięwzięć zaliczanych do obrony kolektywnej NATO. Ocenia się, że w tym obszarze Sojusz powinien znaleźć właściwe proporcje pomiędzy pozyskiwanymi zdolnościami defensywnymi a ofensywnymi. Państwa sojusznicze powinny też dążyć do ochrony i podnoszenia odporności najwrażliwszych na oddziaływanie w cyberprzestrzeni elementów sił zbrojnych i cywilnej infrastruktury krytycznej (Lindley-French, 2017B, s. 22). W tym kontekście szczególnie ważna wydaje się inicjatywa utworzenia wspólnego NATO z Unią Europejską centrum odporności w cyberprzestrzeni (Lindley-French, 2017B, s. 63). Mogłaby ona również dobrze służyć transatlantyckiej wymianie informacji na temat rosyjskich transakcji finansowych, związanych z prowadzeniem niekorzystnych kampanii przeciwko państwom NATO i Unii Europejskiej oraz poprawiać własne działania antykorupcyjne i zapewniać przestrzeganie zasad prawa (Rathke, 2017, s. 5).

Wnioski z przeprowadzonych badań wskazują, że NATO nie może w dalszym ciągu stosować zimnowojennej strategii odstraszania opierającej się na obawie nieuchronnego odwetu i nieopłacalności prowadzenia

7 13.11.2017 roku Ministrowie 23 państw członkowskich UE podpisali dokument o utworzeniu w Unii Europejskiej stałej struktury do współpracy z NATO (Permanent Structured Cooperation - PESCO). Ma ona obejmować obszar polityki obronnej i działań na rzecz zapewnienia bezpieczeństwa. Stworzona formuła współpracy pozwoli na wspólne rozwijanie zdolności obronnych, inwestowanie we wspólne projekty obronne oraz podnoszenie gotowości bojowej sił zbrojnych (Defence..., 2017). 
działań ofensywnych przez potencjalnego agresora. Adaptacja odstraszania do zagrożeń płynących z Rosji powinna uwzględniać fizyczną trudność osiągania celów agresora i świadomość ponoszenia przez niego wysokich kosztów. Taka filozofia odstraszania opierałaby się na posiadaniu przez broniącego się kinetycznych zdolności śmiercionośnych i świadczyła o tym, że zwycięstwo strony atakującej jest niemożliwe lub co najmniej bardzo trudne do osiągnięcia (Mitchell, 2015). W państwach Europy Środkowo-Wschodniej taka strategia mogłaby się wyrażać posiadaniem w basenie Morza Bałtyckiego okrętów podwodnych i zdolności do minowania morskiego, a także różnorodnych, zaawansowanych technologiczne pocisków rakietowych dalekiego rażenia. W wymiarze lądowym przeciwdziałając inwazji można stosować trudne do pokonania przez przeciwnika inteligentne miny, które samoczynnie uzbrajałyby się w przypadku pojawienia się sygnałów o agresji oraz broń przeciwpancerną. Zasadnym jest też posiadanie przez państwa średniej wielkości, takie jak Polska, broni ofensywnych na przykład rakiet manewrujących Cruise średniego zasięgu typu AGM-158 JASSM ${ }^{8}$ lub dalekiego zasięgu Tomahawk ${ }^{9}$, aby razić obiekty położone w głębi terytorium agresora (Grygiel, 2015, s. 40).

Zaproponowana powyżej koncepcja zintegrowanego odstraszania konwencjonalnego i nuklearnego powinna opierać się na integracji wertykalnej, horyzontalnej, funkcjonalnej i czasowej. Integracja wertykalna polega na spójnym zastosowaniu wszystkich dostępnych komponentów odstraszania od nuklearnego poprzez konwencjonalne, aż do niekonwencjonalnego na wszystkich poziomach prowadzenia wojny, włącznie z efektami wywoływanymi zdolnościami posiadanymi przez pojedyncze

8 „JASSM to skrót od «Joint Air-to-Surface Standoff Missile» i oznacza wspólny (dla US Air Force i US Navy) pocisk klasy «standoff», czyli odpalany spoza zasięgu działania obrony powietrznej przeciwnika. AGM-158A JASSM to skrzydlaty pocisk manewrujący o obniżonej wykrywalności, napędzany silnikiem turboodrzutowym umożliwiającym atakowanie celów oddalonych o ponad $370 \mathrm{~km}$. Dokładny zasięg nie został dotąd ujawniony przez producenta, podobnie jak część pozostałych danych technicznych" (Samoloty...).

9 „Poddźwiękowy pocisk manewrujący dalekiego zasięgu Tomahawk uważany jest za najlepszą broń tego typu na świecie. Może atakować cele naziemne (Tomahawk Land Attack Missile - TLAM) oraz nawodne (Tomahawk Anti-ShipMissile - TASM). Może być uzbrojony w głowicę konwencjonalną albo nuklearną (amerykańska armia ma jednak tylko te z głowicami konwencjonalnymi). Tomahawki są skuteczne, praktycznie nie można ich zestrzelić i mogą razić cele w odległości przekraczającej tysiąc mil" (Zadworny, 2015). 
pododdziały. Integracja horyzontalna zapewnia włączenie do działań odstraszających wszystkich podmiotów państwowych i niepaństwowych oraz poprawia skuteczność i efektywność interakcji sektora państwowego i prywatnego. Integracja funkcjonalna uwzględnia wszystkie zasady integracji horyzontalnej, które są stosowane w odniesieniu do funkcji wypełnianych przez stosowne podmioty (państwowe i organizacje niepaństwowe). I wreszcie integracja czasowa polega na integrowaniu wysiłków odstraszania w określonym przedziale czasowym, stosownie do potrzeb występujących w określonej sytuacji (Cornish, 2017).

Odstraszanie konwencjonalne powinno mieć wymiar praktyczny, szczególnie w odniesieniu do wschodniej flanki NATO. Cztery rotacyjne bataliony manewrowe nie mogą skutecznie wypełnić tej roli. Sojusz potrzebuje większych i cięższych sił rozmieszczonych na stałe w państwach Europy Środkowo-Wschodniej. Celowe jest podjęcie decyzji przez Stany Zjednoczone o powrocie do Europy co najmniej jednej lub dwóch ciężkich brygad pancernych wycofanych w 2012 roku, a także większa obecność w wymiarze powietrznym i morskim (Hicks, 2016). Towarzyszyć temu powinny działania dyplomatyczne zapewniające długotrwałą obecność wojsk i szybkie reagowanie co najmniej sił odpowiedzi NATO. Skuteczność odstraszania konwencjonalnego mogą zapewnić zasadnicze siły, które posiadając zaadaptowane do nowych zagrożeń zdolności będą w stanie na czas przybyć w rejon konfliktu. Konieczne są zatem nowe możliwości przeciwstawiania się rosyjskim zdolnościom wzbraniania dostępu do rejonu działań operacyjnych oraz pozyskanie nowych zdolności ofensywnych. Podnoszenie wydatków na obronność i modernizacja sił zbrojnych państw sojuszniczych dobrze wpisują się w proces odstraszania. Norwegia, Dania i Wielka Brytania pozyskują zaawansowane technologicznie myśliwce. W Polsce wdraża się program obrony przeciwlotniczej i przeciwrakietowej, w ramach którego zamierza się zakupić najnowocześniejsze zestawy Patriot Advanced Capability-3. Dąży się do uzbrojenia myśliwców F-16 w pociski manewrujące typu Cruise i pozyskania środków artyleryjskich dalekiego zasięgu (Gotkowska, 2017, s. 5). Inwestycje Norwegii i Wielkiej Brytanii koncentrują się na zakupach nowych samolotów P-8 Posejdon ${ }^{10}$ przeznaczonych do patrolowania akwe-

${ }^{10}$ „W Marynarce Wojennej USA Boeing P-8 Poseidon zastępuje wysłużoną maszynę P-3. Jest to samolot patrolowy i rozpoznawczy, przeznaczony w pierwszej kolejności do niszczenia okrętów podwodnych i nawodnych przeciwnika. Oprócz tego może z powodzeniem zapewniać łączność i dowodzenie na obszarze operacyjnym" (MSPO..., 2017). 
nów morskich i są dobrą odpowiedzią na aktywność rosyjskich okrętów podwodnych w rejonie Północnego Atlantyku. W aspekcie tworzonego dowództwa atlantyckiego wszyscy sojusznicy powinny koncentrować się na wzmocnieniu świadomości sytuacyjnej w regionie Atlantyku i basenie Morza Bałtyckiego (Rathke, 2017, s. 3). Duże korzyści w tym zakresie może przynieść zacieśnienie współpracy ze Szwecją i Finlandią oraz podjęcie kroków zmierzających do przyspieszenia akcesji tych państw do NATO.

Na podstawie przeprowadzonych badań można dojść do wniosku, że rezultatem procesu adaptacyjnego powinno być przedefiniowanie możliwego spektrum prowadzenia przyszłych działań operacyjnych i określenie roli NATO w zapewnianiu bezpieczeństwa euroatlantyckiego. Nowa koncepcja strategiczna wyrażająca sposób zachowania się Sojuszu w przyszłym środowisku bezpieczeństwa międzynarodowego powinna stanowić podstawę do zidentyfikowania wymaganych systemów walki i potrzeb w zakresie sprawowania dowodzenia. Ocenia się, że powinien być to dokument pozwalający na kształtowanie przyszłego środowiska bezpieczeństwa i jednocześnie pozwalać na dokonywanie poprawnych wyborów inwestycyjnych w obszarze obronności przez wszystkie państwa sojusznicze. Koniecznie należy też określić zasady prowadzenia komunikacji strategicznej i wojny informacyjnej. W nowej koncepcji strategicznej powinny też znaleźć się zapisy dotyczące sposobów kształtowania odporności cywilno-wojskowej, w tym kluczowej dla obronności infrastruktury. Należało też będzie wyartykułować wizję prowadzenia zintegrowanego konwencjonalnego, niekonwencjonalnego i nuklearnego odstraszania Sojuszu oraz wykorzystania ofensywnych zdolności do oddziaływania w cyberprzestrzeni (Allen, 2017, s. 15).

\section{Wnioski}

Wnioski z przeprowadzonych badań wskazują, że strategiczny wektor Rosji będzie w dalszym ciągu skierowany przeciwko Zachodowi, a szczególnie państwom Europy Środkowo-Wschodniej. Nic nie wskazuje na to, żeby stosunek do sojuszników miał się zmienić. Rosja już prowadzi ograniczoną wojną hybrydową, w tym w cyberprzestrzeni, aby zastraszyć państwa Europy Środkowo-Wschodniej i osłabić spójność NATO. Nie wiadomo tylko jaki będzie w przyszłości poziom jej agresji. Mimo to, że konflikt zbrojny w Europie wydaje się nierealistyczny, to nigdy nie 
można go wykluczyć. Dlatego też obniżenia napięcia w relacjach NATO z Rosją należy poszukiwać bardziej w sferze politycznej niż militarnej.

Na podstawie przeprowadzonych analiz należy sądzić, że priorytetem dla NATO powinno być uniknięcie scenariusza testowania przez Rosję Zachodu. Z drugiej strony NATO powinno podjąć takie działania, aby wyraźnie komunikować Rosji, że jakiekolwiek wrogie działania wymierzone przeciwko Sojuszowi nie pozostaną bez odpowiedzi. Wydaje się też, że większe zaangażowanie militarne Stanów Zjednoczonych na rzecz Europy Środkowo-Wschodniej może pokrzyżować rewizjonistyczne zapędy Rosji.

Z przeprowadzonych ocen wynika, że bezpieczeństwo obszaru euroatlantyckiego, w tym Europy Środkowo-Wschodniej należy opierać na zmodyfikowanej koncepcji odstraszania, która powinna być zintegrowana strukturalnie i funkcjonalnie. Zaadaptowana do nowych uwarunkowań strategicznych koncepcja powinna uwzględniać zintegrowane działania konwencjonalne, niekonwencjonalne i nuklearne zapewniające odstraszanie i prowadzenie działań obronnych, a także pozwalać na projekcję siły i zapewniać ochroną ludności. Wydaje się, że podstawę odstraszania powinny zapewniać silne wojska i zdolności do działania konwencjonalnego. Koncepcja powinna też obejmować wizję i strategię zaimplementowania nowych technologii pozwalających na odstraszanie niekonwencjonalne. Chodzi tu szczególnie o wykorzystanie możliwości jakie dają sztuczna inteligencja, komputery kwantowe, nanotechnologie, ofensywne zdolności cybernetyczne.

Konieczne jest priorytetowe traktowanie zdolności do obrony kolektywnej, a szczególnie wzbraniających dostępu do obszaru traktatowego. NATO powinno w dalszym ciągu dążyć do wzmocnienia państw Europy Środkowo-Wschodniej poprzez na stałe rozmieszczenie na ich terytorium wojsk posiadających zdolności do działań kinetycznych i wywoływania dewastujących efektów po stronie potencjalnego agresora.

NATO potrzebuje nowej strategii prowadzenia wojny, dostosowanej do obecnych i przyszłych uwarunkowań bezpieczeństwa międzynarodowego. Przyszła koncepcja strategiczna NATO powinna uświadomić sojusznikom potrzebę posiadania narzędzi oddziaływania twardego i miękkiego możliwych do zastosowania w całym spektrum prowadzenia przyszłych działań operacyjnych. Konieczna jest zmiana obecnie obowiązujących zapisów dotyczących kryteriów uruchamiania artykuły 5 Traktatu Waszyngtońskiego. Koncepcja powinna też określać w jaki sposób Sojusz będzie szybko reagował w odpowiedzi na pojawiające się zagrożenia, zasady prowadzenia defensywnych i ofensywnych działań 
w cyberprzestrzeni, defensywnych i ofensywnych działań hybrydowych oraz identyfikować zdolności do prowadzenia hiperwojny.

\section{Bibliografia}

Allen J., Breedlove P. M., Lindley-French J., Zambellasuture G. (2017), War NATO? From Hybrid War to Hyper War via Cyber War, Supporting Paper of the GLOBSEC NATO Adaptation Initiative, Defence\& Security, 20.10, https:// www.globsec.org/wp-content/uploads/2017/10/GNAI-Future-War-NATO-JLF-et-al.pdf, 18.02.2018.

„Ameryka jest w grze i Ameryka zwycięży”. Cztery filary bezpieczeństwa wedhug Trumpa (2018), portal tvn.24, 18.12, https://www.tvn24.pl/wiadomosci-ze-swiata,2/usa-trump-oglosil-nowa-strategie-bezpieczenstwa-narodowego,799709. html, 18.02.2018.

Banasik M., Panek B. (2017), Bezpieczeństwo Sojuszu Pótnocnoatlantyckiego i jego rosyjski problem, „Przedsiębiorczość i Zarządzanie”, t. 18, z. 5, cz. 2: Bezpieczeństwo zewnętrzne $i$ wewnętrzne wobec wspótczesnych wyzwań - wybrana problematyka, red. A. Stępień, s. 143-161, http://piz.san.edu.pl/docs/ e-XVIII-5-2.pdf, 23.02.2018.

„Bild”: Trump nazywa NATO archaicznym i krytykuje UE (2017), Portal internetowy Onet 16.01, https://wiadomosci.onet.pl/swiat/bild-trump-nazywa-natoarchaicznym-i-krytykuje-ue/sjbn7fs, 18.02.2018.

Boston S., Johnson M., Beauchamp-Mustafaga N., Crane Y. K. (2018), Assessing the Conventional Force Imbalance in Europe, Santa Monica, https://www. rand.org/content/dam/rand/pubs/research_reports/RR2400/RR2402/RAND_ RR2402.pdf, 24.02.2018.

Brzezinski I. J.,Valášek T. (2017), Reanimating NATO’s Warfighting Mindset: Eight Steps to Increase the Alliance's Political-Military Agility, Globsec NATO Adaptation Initiative, https://www.globsec.org/wp-content/uploads/2017/07/ GNAI-reanimating-natos-warfighting-mindset.pdf, 18.02.2018.

Cornish P. (2017), Integrated Deterrence: NATO's 'First Reset' Strategy, GLOBSEC NATO Adaptation Initiative, https://www.globsec.org/wp-content/uploads/2017/07/GNAI-Integratted-Deterrrence.pdf, 18.02.2018.

Cyber defence (2018), portal internetowy NATO, 18.02, https://www.nato.int/cps/en/ natohq/topics_78170.htm, 18.02.2018.

Defence cooperation: 23 member states sign joint notification on the Permanent Structured Cooperation (2017), Council of the European Union, http://www. consilium.europa.eu/en/press/press-releases/2017/11/13/defence-cooperation-23-member-states-sign-joint-notification-on-pesco/, 18.02.2018.

Dempsey J. (2017), Nato's Eastern Flank And Its Future Relationship With Russia, Carnegie Endowment for International Peace, Washington, http://carnegieendowment.org/files/CP_318_Eastern_Flank_FNL4WEB.pdf, 18.02.2018. 
Davis I. (2017), NATO seeks faster military movement across Europeandtwo new military commandsto counter Russian threat: A review of the NATO Defence Ministers meeting, Brussels, 8-9 November 2017, Briefing Paper Nr 58, 15.11, http://www.natowatch.org/sites/default/files/2017-11/briefing_paper_ no._58_nato_defence_ministers_meeting_nov_2017.pdf,dostęp: 18.02.2018.

Doran P. B., Bugajski J., Brown M. S. (2017), Strengthening Strategic Security in Central and Eastern Europe, Center for European Policy Analysis, Washington and Warsaw, https://cepa.ecms.pl/files/?id_plik=4896, 16.02.2018.

Dwie nowoczesne rosyjskie korwety Bujan-M na Battyku. Moga przenosić broń atomowa (2016), portal internetowy Wiadomości.pl, 26.10, http://wiadomosci. wp.pl/kat,1329,title,Dwie-nowoczesne-rosyjskie-korwety-Bujan-M-naBaltyku-Moga-przenosic-bron-atomowa,wid,18559523,wiadomosc.html?ticaid $=118085 \&$ ticrsn=3, 24.02.2018.

Dura M. (2017), Rosyjska „prawda” o systemie S-400, Defence24, 26.01.2017, https://www.defence24.pl/rosyjska-prawda-o-systemie-s-400, 22.04.2020.

Gotkowska J., Szymański P. (2017), Russia and the security in the Baltic Sea region. Some recommendations for policy-makers, Baltic Sea Region Policy Briefing series 1/2017, Warszawa, s. 1-10, http://www.centrumbalticum.org/ files/2157/BSR_Policy_Briefing_1_2017.pdf, 18.02.2018.

Hicks K. H., Conley H. A., Samp L. S., Bell A. (2016), Evaluating Future U.S. Army Force Posture in Europe, Washington, https:/csis-prod.s3.amazonaws.com/ s3fs-public/publication/160712_Samp_ArmyForcePostureEurope_Web.pdf, 18.02.2018.

Hodges B. (2015), Department of Defense Press Briefing by General Hodges on Operation Atlantic Resolve in the Pentagon Briefing Room, 09.12, https:// www.defense.gov/News/Transcripts/Transcript-View/Article/633667/department-of-defense-press-briefing-by-general-hodges-on-operation-atlantic-re/, 18.02.2018.

Gac M. (2019), Maritime Safety of NATO Borders in the Baltic Sea Region, „Historia i Polityka", nr 30(37), s. 77-87, http://cejsh.icm.edu.pl/cejsh/element/bwmeta1.element.desklight-0e0b894b-b334-40b8-84b7-8bb52a579e75/c/gac.pdf, 22.03.2020.

Górzyński O. (2016), Rosja znów potrzasa szabelką. Spieszy się przed wyborami w USA?, Portal internetowy wp.pl, 11.10, http://wiadomosci.wp.pl/kat,1356, title,Rosyjski-politolog-decyzja-Putina-potwierdza-nowa-zimnawojne,wid,18538947,wiadomosc.html, 30.08.2016.

Grygiel J. (2015), Arming Our Allies: The Case for Offensive Capabilities, „Parameters" 45(3), Autumn, s. 39-49, https://ssi.armywarcollege.edu/pubs/parameters/issues/Autumn_2015/7_Grygiel.pdf, 18.02.2018.

Henzel P. (2014), Kontrowersje wokół Aktu NATO-Rosja z 1997 r. ,,Trudno mówić, że NATO łamie to porozumienie”, Portal onet.wiadomości 08.12, https://wiadomosci.onet.pl/tylko-w-onecie/kontrowersje-wokol-aktu-nato-rosja-z-1997-rtrudno-mowic-ze-nato-lamie-to/0veqz, 18.02.2018. 
Khramchikhin A. (2018), Rethinking the Danger of Escalation: The Russia-NATO Military Balance, Carnegie Endowment for International Peace, http://carnegieendowment.org/files/Khramchikhin_NATO_web.pdf, 18.02.2018.

Komunikat ze szczytu NATO w Warszawie (2016), Wydany przez Szefów Państw i Rządów uczestniczących w Posiedzeniu Rady Północnoatlantyckiej w Warszawie w dniach 8 i 9 lipca, http://m.mon.gov.pl/d/pliki/rozne/2016/08/Komunikat_ze_Szczytu.pdf, 23.02.2018.

Kuczyński G. (2015), Zachodnia rubież naszpikowana wojskiem. Tutaj Rosja ma przewage nad NATO, Portal tvn.24, https://www.tvn24.pl/wiadomosci-ze-swiata,2/potencjal-militarny-rosji-nad-baltykiem-zachodni-okregwojskowy,530057.html, 24.02.2018.

Lindley-French J. (2017), One Alliance? Change Drivers in a New Strategic Environment, Globsec Nato Adaptation Initiative, https://www.globsec.org/wp-content/uploads/2017/07/GLOBSEC-NATO-ADAPTATION-INITIATIVE_one_alliance_interim_report.pdf, 18.02.2018.

Lindley-French J. (2017B), The Future Tasks of the Adapted Alliance, The GLOBSEC NATO Adaptation Initiative, https:/www.globsec.org/wp-content/uploads/2017/11/GNAI-Final-Report-Nov-2017.pdf, 18.02.2018.

Lorenz W. (2017), Changes to the NATO Command Structure, „Biuletyn PISM”, nr 108 (1048), 14.11, https://www.pism.pl/files/?id_plik=23766, 18.02.2018.

Macierewicz: Do Polski trafi 7 tys. żotnierzy USA i NATO (2017), Portal Defensce24, 13 stycznia, http://www.defence24.pl/macierewicz-do-polski-trafi-7-tyszolnierzy-usa-i-nato, 23.02.2018.

Mitchell A. W. (2015), The Case for Deterrence by Denial, Portal The American interest 12.07, https:/www.the-american-interest.com/2015/08/12/the-case-fordeterrence-by-denial/, 18.02.2018.

Michta A. (2016), Michta: odpowiedź na rosyjski system A2/AD to wielkie wyzwanie dla NATO, „Dziennik Związkowy”, 5.06, http://dziennikzwiazkowy.com/ ameryka/michta-odpowiedz-na-rosyjski-system-a2ad-to-wielkie-wyzwaniedla-nato/, 30.08.2016.

NATO Defence Ministers agree to adapt command structure, boost Afghanistan troop levels (2017), Portal NATO 9.11, https:/www.nato.int/cps/ic/natohq/ news_148722.htm?selectedLocale=en, 18.02.2018.

NATO confirms entry of two Russian warships into Baltic Sea waters, Baltic News Network 27.10.2016, https://bnn-news.com/nato-confirms-entry-of-tworussian-warships-into-baltic-sea-waters-153570, 22.04.2020.

Odporność: kluczowy element obrony zbiorowej (2016), „Przegląd NATO”, https:// www.nato.int/docu/review/2016/Also-in-2016/nato-defence-cyber-resilience/PL/index.htm, 18.02.2018.

Pre-Ministerial press conference by NATO Secretary General Jens Stoltenberg before the meeting of the North Atlantic Council at the level of Defence Ministers (2016), Portal internetowy NATO 13.06, https://www.nato.int/cps/en/natohq/ opinions_132272.htm, 18.02.2018. 
MSPO 2017: Boeing P-8 Poseidon - samolot do zwalczania okrętów (2017), portal internetowy defence.24 8.09, http://www.defence24.pl/mspo-2017-boeing-p8-poseidon-samolot-do-zwalczania-okretow, 18.02.2018.

Rathke J. (2017), Security in Northern Europe and the Road to the 2018 NATO Summit, Center for Strategic and International Studies, 20.11, https://www.csis.org/ analysis/security-northern-europe-and-road-2018-nato-summit, 18.02.2018.

Relations with the European Union (2018), Portal internetowy NATO, 13.02, https:// www.nato.int/cps/ua/natohq/topics_49217.htm, 18.02.2018.

Rosja uzbroi Flotę Battycka w rakiety S-400. „,Polska w zasiegu”, Portal internetowy Wp.pl, https://wiadomosci.wp.pl/rosja-uzbroi-flote-baltycka-w-rakiety-s400-polska-w-zasiegu-6224103254111873a, 24.02.2018.

Samoloty $w$ lotnictwie polskim, http://www.samolotypolskie.pl/samoloty/14821/126/ Lockheed-Martin-AGM-158-JASSM2, 18.02.2018.

Stasik E. (2017), Ben Hodges: siedziba dowództwa logistycznego NATO powinny być Niemcy, Portal internetowy DW 29.11, http://www.dw.com/pl/ben-hodges-siedzib\%C4\%85-dow\%C3\%B3dztwa-logistycznego-nato-powinnyby\%C4\%87-niemcy/a-41575778, 18.02.2018.

Shlapak D. A., Johnson M. (2016), Reinforcing Deterrence on NATO's Eastern Flank. Wargaming the Defense of the Baltics, https:/www.rand.org/content/ $\mathrm{dam} / \mathrm{rand} / \mathrm{pubs} / \mathrm{research}$ _reports/RR1200/RR1253/RAND_RR1253.pdf, 23.02.2018.

Szef NATO: Rozmieszczanie sit na wschodniej flance jest na dobrej drodze (2017), PAP 14.02, http://wiadomosci.dziennik.pl/swiat/artykuly/542686,jens-stoltenbergnato-wschodnia-flanka-wojsko-armia-zolnierze-polska.html, 23.02.2018.

Vandiver J. (2013), US Army's last tanks depart from Germany, Stars and Stripes, 04.04, https://www.stripes.com/news/us-army-s-last-tanks-depart-from-germany-1.214977, 24.02.2018.

Vandiver J. (2017), Mattis, allies eye faster military movement across Europe, Stars and Stripes, 24.10, https://www.stripes.com/news/mattis-allies-eye-fastermilitary-movement-across-europe-1.494134, 18.02.2018.

Vershbow A. (2017), The Political Adaptation of the Alliance, GLOBSEC NATO Adaptation Initiative: Supporting Paper ONE NATO 2017, https://www. globsec.org/wp-content/uploads/2017/07/GNAI-The-Political-Adaptation-of-Aliance.pdf, 18.02.2018.

Waterman S. (2016), Finns plan NATO-EU hybrid warfare center, Portal internetowy Cyberscoop, 29.11, https://www.cyberscoop.com/finns-plan-nato-eu-hybrid-warfare-center/, 18.02.2018.

Xavier A. I. (2016), The (Post) Warsaw NATO Strategy and The Eastern Flank: A Perspective From The South, UA: Ukraine Analytica, Issue 3 (5), https://research. unl.pt/files/2945111/AIX_UkraineAnalytica_3_5_2016.pdf, 16.02.2018.

Zadworny A. (2015), Rakiety manewrujące - polski sen o potędze. Amerykańskie Tomahawki czy francuskie MdCN?, Portal wyborcza.pl, 6.05.2015, http:// 
wyborcza.pl/1,87648,17867617,Rakiety_manewrujace polski_sen_o_potedze_Amerykanskie.html, 18.02.2018.

\title{
The security of Central and Eastern Europe with regard to threats from the Russian Federation
}

\begin{abstract}
Summary
The goal of the Russian Federation's imperial policy is changing the international order established after the end of the Cold War and rebuilding its zone of influence. The aim of the article is to assess the security of Central and Eastern European countries in terms of threats from Russia. The article presents the strategic challenges facing NATO and indicates the desirable directions NATO should take to adapt to the changing determinants of international security.
\end{abstract}

Key words: Central and Eastern Europe, Russia, NATO, adaptation, challenge, security, threats 
